\section{Testes COVID-19 \\ Baseados em Saliva Usando Smartphones}

A pandemia de COVID-19 é provocada pelo coronavírus SARS-CoV-2. 0 teste para despiste da doença envolve a deteção do material genético do vírus usando testes vulgarmente designados por PCR, que se baseiam na Reverse Transcription Polymerase Chain Reaction (RT-PCR). Esta reação em cadeia da polimerase de transcrição reversa origina a multiplicação do RNA do vírus, mas é um processo com algumas limitações devido aos tempos relativamente longos do teste, à capacidade finita de resposta do laboratório e a custos comparativamente elevados.

Para além destas limitações, atualmente a maioria dos testes à COVID-19 requer esfregar a parte superior do nariz ou áreas da garganta, o que pode ser desconfortável e, geralmente, requer profissionais de saúde com equipamento de proteção completo para recolher as amostras. No entanto, o SARS-CoV-2 pode estar igualmente presente na saliva durante o início da infeção, pelo que testes à COVID-19 baseados em saliva podem reduzir ou eliminar o envolvimento de pessoal de saúde para a recolha da amostra, por não serem necessários nem materiais especiais nem experiência.

Tony Y. Hu, da Escola de Medicina da Universidade Tulane, New Orleans, EUA, e colegas desenvolveram uma abordagem ultrassensível e prática para o teste à COVID-19: uma plataforma portátil de smartphone baseada em saliva que fornece resultados em 15 minutos sem envolver o teste laboratorial PCR, exigente em termos de recursos. A equipa de investigação construiu um protótipo de chip de ensaio que usa a enzima CRISPR / Cas12a para aumentar o sinal de um alvo de RNA amplificado numa amostra de saliva. Este chip foi integrado num dispositivo de leitura de microscópio de fluorescência baseado em smartphone, que captura e analisa imagens para determinar se o vírus está presente acima de uma concentração limite.

Os investigadores usaram esta técnica para analisar a saliva de doze pacientes com infeções confirmadas

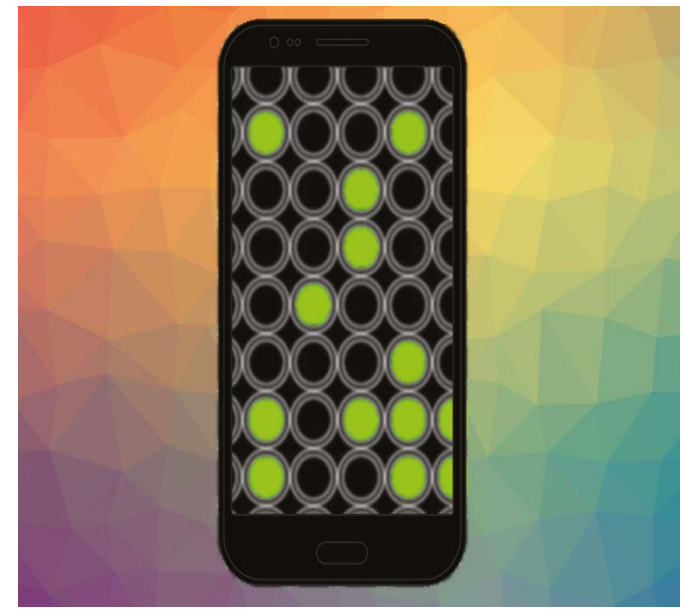

Crédito: Chemistry Views

por COVID-19 e seis controlos saudáveis e verificaram que o método fazia a distinção, com sucesso, entre pacientes com e sem vírus. De acordo com a equipa de investigaação, versões futuras do chip usado nesta técnica podem conter reagentes pré-carregados e controlos de amostra, e uma aplicação de smartphone personalizada pode permitir o envio (wireless) seguro de dados para aplicações de tele-saúde. Os investigadores acreditam que esta plataforma de smartphone, ou uma aplicação futura semelhante, oferece o potencial para expandir rapidamente a capacidade de triagem de COVID-19 e simplificar o rastreio de contactos, de modo a melhorar a contenção local e informar os responsáveis regionais pelo controlo de doenças.

\section{$>$}

\section{Ana Paula Esteves}

aesteves@quimica.uminho.pt

\section{Fontes}

Saliva-Based COVID-19 Tests Using Smartphones, chemistryviews.org/details/ news/11281981/Saliva-Based_COVID-19_Tests_Using_Smartphones.html (acedido em 10/01/2021).

B. Ning, T. Yu, S. Zhang, Z. Huang, D. Tian, Z. Lin, A. Niu, N. Golden, K. Hensley, B. Threeton, C. J. Lyon, X.-Ming Yin, C. J. Roy, N. S. Saba, J. Rappaport, Q. Wei, T. Y. Hu, Sci. Adv. 2021, 7, eabe3703. DOI: 10.1126/sciadv.abe3703.

\section{Tapsigargina - um Promissor Antiviral para o Tratamento da COVID-19}

A estratégia para o controlo a longo prazo do vírus SARS-CoV-2 e de outros vírus respiratórios importantes passa pelo uso de vacinas eficazes, mas necessita de incluir também antivirais para o tratamento de infeções agudas. Enquanto as vacinas COVID-19 es- 
tão em processo de produção para a vacinação em massa, o número modesto de antivirais em uso ou em desenvolvimento para qualquer doença mostra os desafios do desenvolvimento deste tipo de fármaco.

Uma equipa multidisciplinar que inclui investigadores da Universidade de Nottingham, da Agência de Saúde Vegetal e Animal e do Pirbright Institute, Reino Unido, e do Laboratório de Epidemiologia Animal da China descobriram uma nova propriedade antiviral de um fármaco, o que pode ter grandes implicações no modo como serão geridas pandemias futuras, incluindo a de COVID-19. 0 estudo mostra que a tapsigargina, uma lactona sesquiterpénica que pode ser extraída da planta Thapsia garganica, em pequenas doses, desencadeia uma resposta imune inata antiviral, centrada no hospedeiro e altamente eficaz contra três tipos principais de vírus respiratórios humanos, o SARS-CoV-2, o vírus sincicial respiratório (VSR) e o vírus da gripe A. Os investigadores descobriram que a tapsigargina é eficaz contra a infeção viral quando usada antes ou durante a infeção ativa, sendo capaz de impedir que um vírus se replique nas células durante, pelo menos, 48 horas após uma única exposição de 30 minutos. Revelaram que este composto é estável ao pH ácido do estômago pelo que pode ser tomado por via oral, e por isso sem necessidade de injeções ou internamento hospitalar. Para além disso, não evidenciou sensibilidade à resistência do vírus, sendo, pelo menos, várias centenas de vezes mais eficaz do que as opções antivirais atuais.

0 investigador responsável Kin-Chow Chang, afirmou: "Embora ainda estejamos nas etapas iniciais da pesquisa sobre este antiviral e o seu impacto no modo como doenças causadas por vírus como o SARS-CoV-2 podem ser tratadas, estas descobertas são extremamente significativas. A pandemia atual evidencia a necessidade de antivirais eficazes para tratar infeções ativas, bem como vacinas, para prevenir a infeção. Dado que as futuras pandemias muito provavelmente serão de origem animal, onde ocorre a propagação de animal para humano (zoonótica) e zoonótica reversa (humano para animal), uma nova geração de antivirais, como a tapsigargina, pode desempenhar um papel fundamental no controlo e tratamento de infeções virais importantes em humanos e animais."

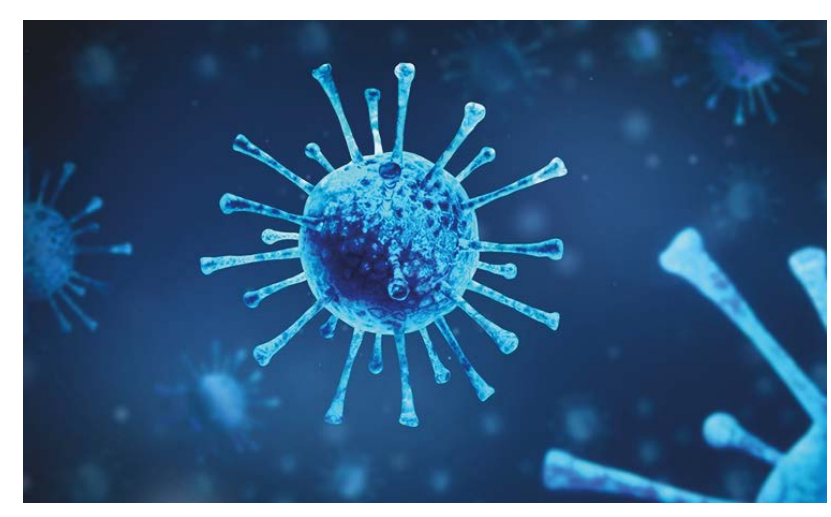

Crédito: Drug Target Reviews<smiles>C/C=C(\C)C(=O)O[C@H]1C(C)=C2[C@@H]3OC(=O)[C@@](C)(O)[C@@]3(O)[C@@H](OC(=O)CCC)C[C@](C)(OC(C)=O)[C@@]2(C)[C@H]1OC(=O)CCCCCCC</smiles>

Ana Paula Esteves

aesteves@quimica.uminho.pt

\section{Fontes}

Thapsigargin could be used as antiviral to treat COVID-19, study shows, drugtargetreview.com/news/82424/thapsigargin-could-be-used-as-antiviralto-treat-covid-19-study-shows (acedido em 03/02/2021).

S. Al-Beltagi, C. A. Preda, L. V. Goulding, J. James, J. Pu, P. Skinner, Z. Jiang, B. L. Wang, J. Yang, A. C. Banyard, K. H. Mellits, P. Gershkovich, C. J. Hayes, J. NguyenVan-Tam, I. H. Brown, J. Liu, K.-Chow Chang, Viruses 2021, 13, 1-20. DOI: 10.3390/ v13020234.

\section{Citronamina A Isolada de uma Esponja Marinha}

Ao longo dos séculos a descoberta de produtos naturais biologicamente ativos facilitou o desenvolvimento de fármacos para combater várias doenças, nomeadamente a malária. A malária é uma doença transmitida por mosquitos, que está disseminada nas regiões tropicais e subtropicais, sendo provocada pelo parasita 